\title{
Memahami Bangsa-bangsa Lain dalam Injil Matius
}

\author{
Adi Putra \\ Sekolah Tinggi Teologi Pelita Dunia \\ addiepoetra7@gmail.com
}

\begin{abstract}
This article described one of the uniqueness of the Gospel of Matthew, namely: the emergence of systemic and consistent elements of other nations (gentile). Though Matthew's Gospel is a gospel written for Jews with an emphasis on fulfilling the Old Testament in Jesus and His ministry. Then, why are the elements of other nations in it? This paper answers it by looking more at the salvation (soteriology) aspects designed by God and also includes other nations in it.
\end{abstract}

Keywords: gentile; the Gospel of Matthew; other nations

Abstrak: Artikel ini menjelaskan salah satu keunikan dari Injil Matius, di mana secara sistematis dan konsisten menjelaskan unsur bangsa-bangsa lain (gentile). Meskipun injil Matius ditulis kepada orang Yahudi dengan sebuah penekanan penggenapan PL dalam Yesus dan pelayanan-Nya. Lalu, mengapa unsur bangsa-bangsa lain dijelaskan secara konsisten dan sistematis di dalamnya? Penelitian ini menjawabnya dengan melihat lebih kepada aspek keselamatan yang telah didesain oleh Allah juga bagi bangsa-bangsa lain

Kata Kunci: bangsa lain; Injil Matius; non-Yahudi

$\begin{array}{llll}\text { Article History : } & \text { Received: 14-12-2018 } & \text { Revised: 20-12-2018 Accepted: 29-12-2018 }\end{array}$

\section{Pendahuluan}

Sebuah pendapat yang sangat umum berkaitan dengan Injil Matius adalah ungkapan yang mengatakan, "Injil Matius adalah Injil yang ditulis kepada bangsa Yahudi, itulah sebabnya injil ini selalu menghindari menggunakan istilah Allah." Hal ini tidak perlu diperdebatkan karena banyak referensi akan sepakat dengan persepsi itu, bahwa Injil ini ditulis kepada orang Yahudi, baik itu di Palestina ataupun yang berada di Siria. ${ }^{1}$ Mark McGarvey mengatakan, "In pursuit of his main purpose, Matthew presents an array

\footnotetext{
${ }^{1}$ Cukup menarik melihat apa yang dikemukakan oleh Richard Baukham, "Kitab-kitab Injil pertama kali ditulis untuk dibaca oleh seluruh orang Kristen, tidak boleh dikesampingkan", (Richard Baukham, ed., The Gospels for All Christians: Rethinking the Gospel Audiences, Grand Rapids, Eerdmans, 1998) bandingkan juga pendapat Craig S. Keener, A Commentary on the Gospel of Matthew, Grand Rapids: Eerdmans, 1999, 45-51.
} 
of prophecies fulfilled in the person of Jesus, of miracles wrought by him and with reference to him, of characteristics posseseed by him, and of predictions uttered by him, which constitute an overwhelming proof of his Messiahship and his divinity."2 Maksudnya, Matius menyajikan serangkaian nubuat yang digenapi dalam diri Yesus, tentang mukjizat yang dilakukan olehnya dan dengan referensi kepadanya, karakteristik yang dimiliki olehnya, dan prediksi yang diucapkan olehnya, yang merupakan bukti yang luar biasa dari kemesiasan dan keilahian-Nya.

Howard Clarke menambahkan,

Matthew's Jesus is a teacher, preacher, and lawgiver in the tradition of Moses, whose career offers precedents for episodes in Jesus' own life, particularly his infancy and his Sermon on the Mount. But Matthew goes on to present Jesus also as the fulfillment of Israel's messianic hopes, which seems to have been a significant issue for his own community. ${ }^{3}$

Maksudnya, Yesus dalam pembahasan Matius adalah seorang guru, pengkhotbah, dan pemberi hukum dalam tradisi Musa, yang kariernya menawarkan preseden untuk episode dalam kehidupan Yesus sendiri, khususnya masa kecilnya dan Khotbah di BukitNya. Tetapi Matius melanjutkan untuk menyajikan Yesus juga sebagai pemenuhan harapan mesianik Israel, yang tampaknya telah menjadi masalah yang signifikan bagi komunitasnya sendiri. Pada intinya, McGarvey dan Clarke memiliki pendapat yang sama.

Matius memang berupaya menunjukkan bahwa setiap peristiwa dalam kehidupan atau pun dalam perbuatan dan karya Tuhan Yesus menggenapi setiap nubuat-nubuat dalam Perjanjian Lama. Injil Matius mengemukakan jati diri Tuhan Yesus dalam ungkapan-ungkapan yang memiliki hubungan atau pun memiliki latar belakang dengan Perjanjian Lama. Gelar-gelar yang selalu dialamatkan kepada Tuhan Yesus, seperti: Anak Manusia dan Anak Allah; bahkan seringkali dalam Injil juga dijumpai dikemukakan bahwa Yesus adalah Anak Daud, Mesias atau Kristus - semuanya itu memiliki hubungan yang sangat erat atau dekat dengan Perjanjian Lama. Oleh karena bukanlah pendapat yang keliru apabila diasumsikan bahwa memang kitab ini memiliki relasi yang cukup dekat dengan bangsa Yahudi. ${ }^{4}$

Akan tetapi bukan berarti tidak ada unsur "bangsa-bangsa lain" (gentile) di dalamnya. Oleh karena ada hal yang menarik, di mana sejak pasal 1 kitab ini, penulis

\footnotetext{
2 Mark McGarvey, The New Testament Commentary Volume 1Matthew and Mark, (Washington: Librarian of Congress, 1875), hlm. 10.

${ }^{3}$ Howard Clarke, The Gospel of Matthew and Its Readers: A Historical Introduction to the First Gospel, (North Morton Street Bloomington, Indiana: Indiana University Press,2003), hlm.xviii.

${ }^{4}$ McGarvey menambahkan, "While Matthew maintains throughout his narrative a purely Christian spirit, he looks at every thing with Jewish eyes, and keeps his own countrymen in view as his readers. He is not unmindful of the fact that many of his Jewish kinsmen spoke only the Greek language, and consequently he sometimes translates into Greek Hebrew words which he has occasion to employ. But, unlike the other historians, he omits those explanations of Jewish customs and of local references, which Gentile readers would naturally expect (Comp, Mark vii. 3, 4;r iii, 3) ; yet he devotes more attention than do all of the others to the fulfillments of prophecy; and he is alone in giving that line of ancestry by which Jesus was heir of the throne of David."
} 
telah memasukkan beberapa tokoh yang tidak berasal dari bangsa Israel dalam silsilah Yesus (hal yang justru tidak dimunculkan oleh Lukas dalam Injil yang ditulisnya). Hal itu berlanjut hingga kelahiran Yesus, pelayanan Yesus sampai hingga amanat agung atau perintah memberitakan Injil kepada setiap murid-Nya di 28: 19-20 di mana di sana

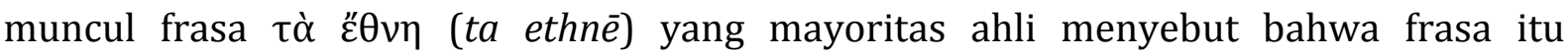
dialamatkan kepada bangsa-bangsa lain di luar bangsa Yahudi. "Untuk konteks Matius 4:15, kata ini menunjuk kepada orang-orang non-Israel yang pada zaman Yesus telah menetap dan tinggal di wilayah Kapernaum atau Galilea secara umum". ${ }^{5}$ Oleh karena pada zaman Yesus di wilayah Galilea termasuk Kapernaum telah tinggal bangsa-bangsa lain juga - tidak hanya orang Yahudi saja.

\section{Metode Penelitian}

Ini merupakan penelitian kualitatif yang menggunakan pendekatan literatur, yaitu kitab Injil Matius. Metode yang digunakan adalah deskriptif untuk memberikan gambaran tentang "bangsa lain" yang ada dalam Injil Matius. Metode analisis digunakan untuk memahami maksud penggunaan istilah "bangsa lain" dalam Injil Matius dengan menggali istilah dari bahasa Yunani yang menunjukkan istilah tersebut.

Kata $\dot{\varepsilon} \theta v \tilde{\omega} v$ (ethnon) dapat dipahami dalam beberapa pengertian, yakni: (1) disatukan oleh seseorang melalui pertalian kekeluargaan, budaya, tradisi, negara, dan orang; (2) kelompok orang-orang asing yang spesifik pada sebuah kelompok tertentu: mereka yang tidak termasuk dalam kelompok orang yang menyatakan iman di dalam Allah Israel, bangsa-bangsa, bukan Yahudi, dan bukan orang percaya; orang Kristen nonIsrael, umat Kristen yang terdiri dari bangsa-bangsa lain yang terdiri dari beberapa bangsa atau tidak dibatasi hanya kepada orang Israel. ${ }^{6}$

Apakah benar demikian? Dan apakah maksudnya penulis Injil Matius memasukkan unsur gentile dalam Injil yang ditulisnya? Dua pertanyaan inilah yang kemudian akan dijawab dan dijabarkan dalam penelitian ini.

\section{Pembahasan}

\section{Unsur-unsur Gentile dalam Injil Matius}

Unsur-unsur Gentile dalam Injil Matius sangat gamblang dideskripsikan oleh Matius bahkan melebihi atau setidaknya sama dengan tiga Injil Kanonik yang lain. Perhatikan diagram di bawah ini!

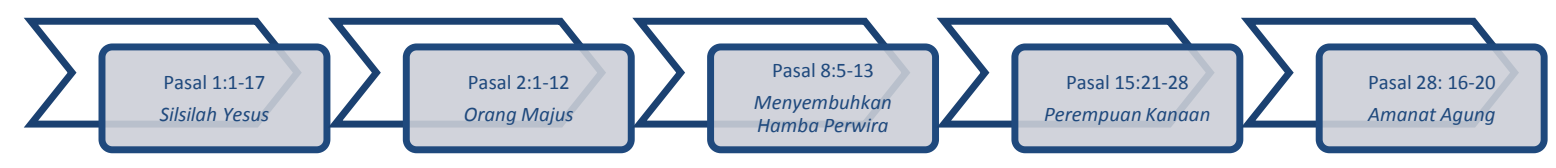

5 Adi Putra, Misi Yesus kepada Bangsa-bangsa Lain: Kajian Biblika terhadap Pelayanan Yesus di Galilea berdasarkan Matius 4:12-17, (Jakarta: Penerbit Vieka Wahana Semesta, 2015), hlm. 156.

${ }^{6}$ Bauer's, Walter. A Greek-English Lexicon of The New Testament And Other Early Christian Literature (BDAG) Third Edition. Chicago: The University of Chicago Press, 2000. Diedit oleh: Frederick William Danker, hlm. 276-77. 
Dari diagram di atas menunjukkan Injil Matius juga mendeskripsikan unsur bangsa-bangsa lain secara merata. Dimulai dengan memasukkan empat perempuan yang bukan berasal dari orang Israel di dalam Silsilah Yesus, yakni: Tamar, Rahab, Rut, dan Batsyeba. Dilanjutkan dengan menjelaskan kunjungan orang Majus ketika Yesus lahir. Kunjungan atau sambutan ini menjadi spesial karena bangsa Israel sendiri (diwakili oleh sikap Herodes) justru menjadi kuatir bahkan "tidak menginginkan" kelahiran Yesus. Tentunya sikap ini bertolak belakang dengan sikap orang-orang Majus.

Kemudian dalam pelayanan, Yesus pernah menyembuhkan hamba perwira dan anak seorang perempuan Kanaan yang bukan orang Israel. Bahkan masih dalam pelayanan Yesus dalam pemaparan Matius menunjukkan durasi waktu yang cukup panjang Yesus melayani di Galilea, yang dalam Injil Matius disebut sebagai wilayah bangsa-bangsa lain. Seperti seolah-olah disengaja oleh Matius, maka Injil ini ditutup dengan sebuah perintah (dikenal dengan Amanat Agung) untuk memberitakan Injil kepada seluruh bangsa (dalam konteks ini bangsa-bangsa lain juga). Jadi Injil ini dibuka dan ditutup dengan unsur gentile. Ini menjadi sangat unik karena seperti yang telah diketahui bersama bahwa Injil Matius sangat kental dengan unsur Yahudinya.

\section{Silsilah Yesus}

Injil Matius mengawali penjelasannya dengan mencantumkan silsilah Yesus dari Yusuf. Ada beberapa keunikan ${ }^{7}$ Injil Matius menjelaskan tentang silsilah Yesus. Salah satunya adalah ketika Matius memasukkan nama-nama perempuan ke dalam penjelasan silsilah Yesus. Sesuatu yang tidak lumrah dalam kebiasaan Yahudi. Kalau pun ada, mungkin orang Yahudi memasukkan nama em pat perempuan yang cukup istimewa bagi mereka, seperti: Sara, Ribka, Rahel, dan Lea. Akan tetapi Matius justru memasukkan nama empat perempuan yang dianggap bukan berasal dari orang Yahudi, yakni: Tamar, Rahab, Rut, dan Batsyeba. Tamar adalah perempuan Kanaan yang kemudian menikah dengan putra-putra Yehuda bahkan akhirnya menjadi istri Yehuda. Kemudian Rahab adalah perempuan Yerikho yang juga dipakai Tuhan untuk menolong para pengintai Israel. Rut adalah perempuan Moab yang merupakan menantu dari Naomi yang akhirnya memperoleh penebusan dari Boas. Terakhir, Batsyeba yang adalah istri Uria orang Het, yang kemudian direbut oleh Daud. Apakah maksudnya keempat perempuan di atas dimasukkan ke dalam silsilah Yesus?

Menurut Morris, “Tiga dari empat wanita ini memiliki reputasi moral yang meragukan. Matius jelas berkata bahwa injil adalah bagi semua orang, tidak hanya bagi orang Yahudi, dan injil adalah untuk orang berdosa. Ini adalah dunia yang berdosa, dan

\footnotetext{
7 Beberapa keunikan ini seperti mengawalinya dengan menyebut Yesus sebagai anak Daud baru kemudian anak Abraham. Kemudian ada tiga kali empat belas keturunan yang dicantumkan oleh Matius. Kemudian Matius juga memasukkan nama-nama perempuan ke dalam silsilah ini.
} 
Matius sedang menulis tentang anugerah". ${ }^{8}$ Dari apa yang dikemukakan oleh Morris di atas menunjukkan bahwa Matius hendak menjelaskan bahwa Injil atau keselamatan dari Allah tidak hanya secara eksklusif ditujukan kepada bangsa Yahudi, melainkan juga kepada bangsa-bangsa lain. Pendapat ini juga dikuatkan oleh de Heer dengan mengatakan, "Perempuan-perempuan asing itu disebut oleh Matius untuk memperlihatkan bahwa Tuhan menerima bangsa-bangsa yang bukan Yahudi dalam rencana keselamatan, atau dengan kata lain: Matius memperlihatkan di sini, bahwa Injil adalah universal". ${ }^{9}$ Ditambahkan oleh Grant R. Osborne, "This along with appearance of the Magi stresses at the outset the Gentile mission toward which Matthew is building (28:18-20) and shows that all humanity is involved in the birth of the Messiah".10

Itulah sebab nya, ketika mencatat keempat perempuan non-Yahudi ke dalam silsilah Yesus, maka Matius tentu melakukannya dengan sengaja atau dengan sebuah tujuan. G. Kittel menambahkan, "Jumlah dan nama wanita yang dipilih bersifat disengaja, bukan ada begitu saja. Penulis ingin menyampaikan sesuatu". ${ }^{11}$ Artinya ada kesengajaan dan ada tujuan Matius mencantumkan keempat nama perempuan non-Yahudi dalam silsilah Yesus. Apabila mengkomparasikan dengan pandangan Morris, maka tujuan itu berkaitan dengan injil yang untuk orang-orang berdosa bukan hanya dari kalangan Yahudi melainkan juga non-Yahudi.

\section{Kelahiran Yesus}

Dalam kisah kelahiran Yesus yang ditulis oleh Matius dan berbau gentile adalah kisah tentang kunjungan orang Majus. J.J. de Heer mengatakan, "Kata Yunani yang dipakai di sini berbunyi Magoi. Pada aslinya, kata itu berarti imam-imam di Persia, tetapi secara luas dipakai untuk orang yang tahu tentang ilmu rahasia dan untuk tukangtukang sihir".12 Dari pendapat de Heer menyatakan bahwa mereka bukan orang Yahudi atau lebih tepatnya bangsa-bangsa lain. Morris memberikan pendapat tentang ini dengan mengatakan,

Sangat mungkin Matius memasukkan kisah orang Majus untuk menyingkapkan kebenaran bahwa Yesus adalah Tuhan atas semua orang; karena Yesus adalah

\footnotetext{
${ }^{8}$ Leon Morris, Tafsiran Injil Matius, (Surabaya: Momentum, 2016), hlm. 24.

${ }^{9}$ J.J. de Heer, Tafsiran Injil Matius, (Jakarta: BPK Gunung Mulia, 2008), hlm. 14.

10 Grant R. Osborne, Exegetical Commentary on The New Testament: Matthew, (Michigan: Grand Rapids, 2010), 63.

${ }^{11}$ G. Kittel, Theological Dictionary of the New Testament (TDNT) III, Michigan: Grand Rapids, 196467), hlm. 1.

12 J.J. de Heer, Tafsiran Injil Matius, hlm. 22. Ditambahkan oleh de Heer, "Dalam ayat 2 orang Majus itu mengatakan, bahwa mereka sudah melihat bintang raja Yahudi di Timur (dapat diterjemahkan dengan: dalam terbitnya). Dan itu menjadi jelaslah bahwa mereka adalah astrolog-astrolog yaitu orang yang mencoba menentukan arti bintang-bintang di langit untuk sejarah dunia. Astrologi pada zaman Perjanjian Baru sangat lazim di antara orang kafir, yang memang tidak mengetahui bahwa astrologi dilarang oleh Tuhan. Di mana "Timur" yang dari sana orang Majus datang? Biasanya dianggap bahwa itu Babilonia, yang terletak di sebelah Timur Palestina. Babilonia merupakan pusat astrologi dan di Babilonia banyak orang Yahudi tinggal, sehingga meskipun orang Majus itu (walaupun orang Kafir) sudah mendengar sedikit tentang seorang Mesias, yaitu raja besar yang kedatangannya diharapkan oleh orang Yahudi ( 22-23).
} 
Tuhan atas semua orang, adalah sesuai dengan kelahiran-Nya, orang datang dari negeri yang jauh untuk memberikan penghormatan. Di dalam narasi ini, orangorang Yahudi beserta raja mereka memusuhi bayi Yesus, tetapi orang-orang nonYahudi justru menghormati Dia. ${ }^{13}$

Apabila pendapat Morris di atas benar, maka hampir dapat dipastikan bahwa sekali lagi Matius hendak menekankan bahwa bangsa-bangsa lain pun memiliki tempat dalam rencana kekal Allah berkaitan dengan keselamatan di dalam Yesus Kristus. Fenton memberikan pendapat yang menegaskan pendapat di atas, "Di pasal ini, Matius memperkenalkan tema utama Injilnya: orang Yahudi menolak tawaran keselamatan, tetapi orang non-Yahudi menerimanya.. Orang non-Yahudi dibawa masuk ke tempat yang ditinggalkan oleh orang Yahudi akibat ketidakpercayaan mereka". ${ }^{14}$

Sehingga sekali lagi hal ini sangat erat hubungannya dengan nuansa soteriologis bagi orang-orang non-Yahudi. Meskipun injil ini ditujukan kepada orang-orang Yahudi, akan tetapi isinya tentang bagaimana ketidaksetiaan sebagian besar mereka kepada Allah, maka tempat kosong yang mereka tinggalkan kemudian diisi oleh bangsa-bangsa lain yang percaya kepada Yesus. Bukan berarti tidak ada sama sekali orang Yahudi yang kemudian memperoleh keselamatan di dalam Kristus. Akan tetapi sebagian besar dari mereka pada kenyataannya telah mengeraskan hatinya untuk tetap tidak percaya kepada Yesus sebagai Mesias, yang kemudian "menguntungkan" bagi bangsa-bangsa lain, seperti yang dicatat dalam Injil Matius.

\section{Pelayanan Yesus}

Berbicara pelayanan Yesus, maka lebih separoh misi Yesus dikerjakan di wilayah Galilea, yang dalam Injil Matius disebut wilayah bangsa-bangsa lain. Jacob van Bruggen mengatakan, "Tuhan Yesus melayani di sana hampir dua tahun - meskipun dalam beberapa waktu Dia sering juga mengadakan perjalanan ke Yerusalem untuk menghadiri perayaan di sana". ${ }^{15}$ Dengan demikian, apabila disepakati bahwa Yesus melayani selama tiga tahun, maka mayoritas waktu pelayanan dihabiskan di wilayah Utara atau wilayah Galilea. Dan itu artinya Dia akan lebih banyak menghabiskan waktu untuk bertemu dan melayani orang-orang non-Yahudi. ${ }^{16}$

Berkaitan dengan pelayanan Yesus kepada bangsa-bangsa lain, maka Injil Matius setidaknya mencatat dua kisah yang melibatkan bangsa-bangsa lain dalam misi dan pelayanan Yesus, yakni: Yesus menyembuhkan hamba seorang perwira dan Yesus menyembuhkan anak seorang perempuan Kanaan (Siro-Fenisia). Ketika Matius mendeskripsikan tentang kisah Yesus menyembuhkan hamba perwira di Kapernaum

\footnotetext{
${ }^{13}$ Leon Morris, Tafsiran Injil Matius,.36-7.

${ }^{14}$ Morris, Tafsiran Injil Matius, 37.

15 Jacob van Bruggen, Kristus di Bumi, (Jakarta: BPK Gunung Mulia, 2001), 185.

16 Dalam buku Misi Yesus kepada Bangsa-bangsa Lain, dikatakan, "Berdasarkan lamanya Yesus melayani di wilayah tersebut (Galilea), maka tidak salah apabila dalam keempat Injil (khususnya Injil Sinoptik) memberikan ruang cukup besar untuk membahas pokok itu - misalnya Injil Matius membahasnya dengan 14 pasal....". (Adi Putra, Misi Yesus kepada Bangsa-bangsa Lain, hlm. 77).
} 
(Mat. 8:5-13), maka penekanan Matius fokus pada iman dan kebangsaan si perwira. Dengan demikian sekali lagi Matius hendak menekankan iman datang dari orang nonYahudi. Karena menurut Morris, "Perwira itu bisa jadi bertugas sebagai tentara Herodes Antipas; ia mungkin bukan orang Roma, tetapi ia pasti bukan orang Yahudi (ay. 8, 10)". ${ }^{17}$

Akan tetapi meskipun perwira tersebut bukan orang Yahudi namun Yesus mengabulkan permintaannya. Mengapa? Apabila membaca apa yang dikatakan Yesus dalam ayat 10, maka jelas menunjukkan bahwa si perwira memiliki iman yang besar. Bahkan Yesus mengatakan bahwa tidak menemukan iman sebesar itu di antara orang Israel.

Selanjutnya, kisah tentang Yesus menyembuhkan anak seorang perempuan Kanaan. Ketika Yesus ditolak oleh orang Yahudi sehingga memaksanya menyingkir pergi ke wilayah Tirus dan Sidon, akan tetapi justru sekali lagi Yesus memperoleh penghormatan dan penerimaan dari orang non- Yahudi. Bahkan menyebut Yesus dengan sebutan "Anak Daud", yang seharusnya tidak diketahui oleh orang non-Yahudi. Menurut Morris, "Dari kisah tentang permusuhan yang sengit, Matius beralih ke sebuah kisah iman yang sangat mengesankan dan di luar dugaan. Ini ada satu dari sedikit kisah penyembuhan yang melibatkan orang non-Yahudi". ${ }^{18}$ Kisah perempuan Kanaan ini memiliki kemiripan dengan kisah Yesus menyembuhkan hamba seorang perwira di Kapernaum. Karena keduanya menekankan tentang iman yang besar yang justru dimiliki oleh orang non-Yahudi.

Dengan demikian, unsur soteriologis sangat jelas terlihat dalam bagian ini. Ketika orang-orang Yahudi menolak dan mengeraskan hatinya kepada Yesus dan pemberitaan yang disampaikan Yesus, maka justru penerimaan dan penyambutan yang hangat diterima oleh Yesus dari kelompok bangsa-bangsa lain.

\section{Perintah Yesus: Amanat Agung}

Bagian ini merupakan bagian terakhir dari penjelasan Matius tentang bangsabangsa lain dalam injilnya. Yang menarik di sini, karena bagian ini terjadi pascakebangkitan Yesus atau sebelum Yesus terangkat ke surga. Itu artinya ada semacam konsistensi dalam pandangan Matius ketika mendeskripsikan sikap dan pandangan Yesus terhadap pentingnya orang-orang non-Yahudi dalam rencana keselamatan Allah. Dalam Matius 28:19, muncul frasa "segala bangsa". Memang frasa ini banyak menimbulkan diskusi di kalangan ahli dan teolog. Misalnya D. R. A. Hare dan D. J. Harrington mengatakan, segala bangsa di sini merujuk semua non-Yahudi tetapi bukan orang Yahudi. Akan tetapi kemudian dijawab atau tepatnya disanggah oleh J.P. Meier dengan mengatakan segala bangsa meliputi bangsa-bangsa di dunia termasuk Israel. ${ }^{19}$

\footnotetext{
17 Leon Morris, Tafsiran Injil Matius, hlm. 199.

${ }^{18}$ Leon Morris, Tafsiran Injil Matius, hlm. 410.

${ }^{19}$ Leon Morris, Tafsiran Injil Matius, hlm. 760.
} 
Akan tetapi, yang pasti dan yang jelas dari kedua pendapat di atas adalah keduanya sepakat bahwa ungkapan di atas menekankan tentang bangsa-bangsa non-Yahudi. Frasa

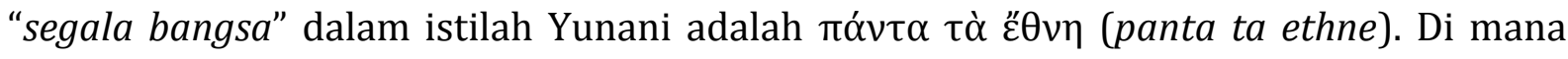
mayoritas ahli setuju bahwa istilah ini memang erat hubungannya dengan bangsabangsa lain. John Riches mengatakan:

Matthew's Gospel concludes with an extraordinary passage in which Jesus claims that 'all authority in heaven and earth has been given' to him and therefore charges his disciples to go and make disciples of all the nations, baptizing them and teaching them to observe all that he has commanded them. This clearly breaks the ban which Jesus had placed on mission to the Gentiles (Matt. 10.5, 6, cf. especially: 'Go nowhere among the Gentiles') and also represents the transcendence/ clarification of the titles which Jesus was given at the beginning of the gospel: son of David, son of Abraham. The Davidic messiah will rule, not just over his own people, the people of Israel, but over all nations (the whole world, including Jews and Gentiles). The manner of his rule will be through the teaching of his commandments and his disciples' obedience to them. ${ }^{20}$

Riches hendak mengatakan, Injil Matius diakhiri dengan sebuah bagian yang luar biasa di mana Yesus mengklaim bahwa "semua otoritas di surga dan bumi telah diberikan" kepada-Nya, dan menuntut para murid pergi, menjadikan semua bangsa murid Kristus.

Kemudian membaptis dan mengajar mereka. Ini jelas bertolak belakang dengan larangan yang telah Yesus sampaikan pada misi kepada orang bukan Yahudi (bdk. Mat. 10:5, 6, lih. khusunya: "Pergi jangan ke tempat di mana ada orang-orang bukan Yahudi") dan juga mewakili transendensi/klarifikasi dari gelar-gelar yang diberikan Yesus pada mulanya. Injil: putra Daud, putra Abraham. Mesias Daud akan memerintah, tidak hanya atas rakyatnya sendiri, orang-orang Israel, tetapi atas semua bangsa (seluruh dunia, termasuk orang Yahudi dan orang bukan Yahudi). Cara pemerintahannya akan melalui pengajaran perintah-perintahnya dan kepatuhan murid-muridnya kepada mereka. Akan tetapi, pendapat Riches sebenarnya hendak menegaskan bahwa memang tidak dapat dipungkiri tentang gentile yang ternyata masuk dalam rencana kekal Allah. Meskipun seolah-olah itu tidak terlihat sejak awal.

Dengan demikian, sekali lagi unsur kasih Allah kepada kelompok gentile dalam bagian ini terlihat dengan jelas. Dan tendensi keselamatan bagi bangsa-bangsa lain juga terlihat dalam bagian ini. Itulah sebabnya, ketika Yesus Kristus disalibkan dan mati, maka kematian-Nya untuk segala bangsa, bukan hanya orang Yahudi saja. Karena segala bangsa adalah manusia berdosa yang memerlukan keselamatan.

\section{Tujuan Matius Memasukkan Unsur Gentile dalam Penulisan Injilnya}

Lalu pertanyaan penting yang harus dijawab yang berkaitan dengan tema atau topik ini, yakni: apa tujuan Matius memasukkan unsur gentile ke dalam Injilnya?

20 John Riches, Matthew's Missionary Strategy In Colonial Perspective dalam buku The Gospel of Matthew in its Roman Imperial Context, (London/New York: T\&T Clark International, 2005), hlm. 128. Diedit oleh: John Riches dan David C. Sim. 
Padahal apabila membaca Injil ini maka sifat keyahudiannya sangat kental. Apakah ini memiliki nuansa soteriologis. Di mana keselamatan yang sedang dikerjakan oleh Yesus, yang kemudian ditolak oleh bangsa Yahudi kemudian diberikan kepada bangsa-bangsa lain. Morris mengatakan:

Matius tertarik dengan bagaimana bangsa-bangsa lain bisa mengikut Yesus. Meskipun universalisme ala Paulus atau Lukas tidak ditemukan di sini, terdapat suatu keteguhan bahwa bangsa-bangsa lain memiliki ruang di dalam skema ilahi, khususnya di dalam menerima pengajaran dan pertolongan Yesus. Matius melaporkan kedatangan orang Majus untuk melihat bayi Yesus, banyak mencatat tentang "Galilea, wilayah bangsa-bangsa lain", dan menuliskan kisah seperti menyembuhkan hamba perwira asing dan penyembuhan anak perempuan dari seorang wanita Kanaan. ${ }^{21}$

Pendapat Morris di atas menekankan bahwa dalam menyusun injilnya, Matius tetap tertarik untuk menjelaskan tentang injil dan keselamatan yang tidak hanya diperuntukkan secara eksklusif bagi orang Yahudi, tetapi juga bagi seluruh bangsa. Artinya, meskipun Injil Matius diperuntukkan bagi orang Yahudi, akan tetapi Injil atau keselamatan yang dideskripsikan dalam Injil Matius diperuntukkan bagi semua bangsa.

Berdasarkan pembahasan sebelumnya tentang unsur-unsur gentile dalam Injil Matius yang berkaitan dengan silsilah Yesus, kelahiran Yesus, pelayanan Yesus, dan amanat agung; maka di sana dijumpai dengan jelas betapa kuatnya nuansa soteriologis di dalamnya. Akan tetapi, juga tidak terlepas dari sikap orang Yahudi yang "menolak" Injil itu sendiri. Jadi, ini seperti satu mata uang dengan dua sisi, yang saling terkait dan tidak dapat terpisahkan.

Seperti perkataan perempuan Kanaan kepada Yesus: “Benar Tuhan, namun anjing itu makan remah-remah yang jatuh dari meja tuannya" (Mat. 15:27). Sepintas, ungkapan ini dapat dimaknai bahwa ketika Injil itu tidak sepenuhnya diterima oleh orang Yahudi, maka di situlah bangsa-bangsa lain mendapat tempat untuk memperoleh anugerah keselamatan melalui Yesus Kristus.

Rencana besar Allah (God's Grand Design) yang telah dimulai sejak penciptaan, di mana Matius berhasil menyajikan Yesus sebagai penggenapan rencana Allah untuk keselamatan bukan hanya bagi bangsa Israel tetapi mencakup bangsa-bangsa lain. ${ }^{22}$

\section{Kesimpulan}

Setelah menguraikan dengan panjang-lebar topik ini, maka sebagai penutup akan dikemukakan beberapa kesimpulan, yakni: pertama, Munculnya unsur-unsur gentile dalam Injil Matius menjadi salah satu keunikan dari pada Injil Matius. Oleh karena seperti yang diketahui bahwa injil Matius ditujukan kepada orang Yahudi dan hendak

${ }^{21}$ Leon Morris, Tafsiran Injil Matius, hlm. 6.

22 Bandingkan: Sonny Eli Zaluchu, Biblical Theology: Pembahasan Metodologi dan Pendekatan Biblika dalam Membangun Teologi PL dan PB yang Alkitabiah, (Semarang: Golden Gate Publishing, 2017), 104. 
menekankan tentang Mesias atau penggenapan PL yang terjadi dalam diri Yesus. Kedua, Unsur-unsur Gentile dalam Injil Matius dijelaskan secara konsisten dan merata dengan meliputi seluruh aspek misi dan pelayanan Yesus. Mulai dari silsilah, kelahiran, pelayanan, hingga amanat agung yang disampaikan oleh Yesus pasca-kebangkitan dan sebelum kenaikan-Nya ke surga. Ketiga, Tujuan dimasukkannya unsur-unsur gentile dalam injil ini sangat erat hubungannya dengan berita keselamatan dalam Kristus yang ternyata juga memasukkan bangsa-bangsa lain sebagai bagian yang tidak terpisahkan darinya. Sehingga nuansa soteriologis sangat jelas terlihat di dalam tujuannya.

\section{Referensi}

Bauer's, Walter. A Greek-English Lexicon of The New Testament And Other Early Christian Literature (BDAG) Third Edition. Chicago: The University of Chicago Press, 2000. Diedit oleh: Frederick William Danker.

Baukham, Richard ed., The Gospels for All Christians: Rethinking the Gospel Audiences, Grand Rapids, Eerdmans, 1998.

Clarke, Howard. The Gospel of Matthew and Its Readers: A Historical Introduction to the First Gospel, North Morton Street Bloomington, Indiana: Indiana University Press,2003.

de Heer, J.J. Tafsiran Injil Matius, Jakarta: BPK Gunung Mulia, 2008.

Keener, Craig S. A Commentary on the Gospel of Matthew, Grand Rapids: Eerdmans, 1999.

Kittel, G. Theological Dictionary of the New Testament (TDNT) III, Michigan: Grand Rapids, 1964-67.

McGarvey, Mark. The New Testament Commentary Volume 1Matthew and Mark, Washington: Librarian of Congress, 1875.

Morris, Leon. Tafsiran Injil Matius, Surabaya: Momentum, 2016.

Putra, Adi. Misi Yesus kepada Bangsa-bangsa Lain: Kajian Biblika terhadap Pelayanan Yesus di Galilea berdasarkan Matius 4:12-17, Jakarta: Penerbit Vieka Wahana Semesta, 2015.

Riches, John. Matthew's Missionary Strategy In Colonial Perspective dalam buku The Gospel of Matthew in its Roman Imperial Context, London/New York: T\&T Clark International, 2005. Diedit oleh: John Riches dan David C. Sim.

van Bruggen, Jacob. Kristus di Bumi, Jakarta: BPK Gunung Mulia, 2001.

Eli Zaluchu, Sonny, Biblical Theology: Pembahasan Metodologi dan Pendekatan Biblika dalam Membangun Teologi PL dan PB yang Alkitabiah, Semarang: Golden Gate Publishing, 2017 